\title{
Potential of Distilled Liquid Smoke Derived from Coconut (Cocos nucifera L) Shell for Traumatic Ulcer Healing in Diabetic Rats
}

\author{
Meircurius Dwi Condro Surboyo $0^{1,2, \odot}$ \\ Taufan Bramantoro ${ }^{6}$ \\ ${ }^{1}$ Faculty of Dental Medicine, Universitas Airlangga, Surabaya, \\ Indonesia \\ 2Department of Oral Medicine, Faculty of Dental Medicine, \\ Universitas Airlangga, Surabaya, Indonesia \\ ${ }^{3}$ Department of Oral Biology, Faculty of Dental Medicine, \\ Universitas Airlangga, Surabaya, Indonesia \\ ${ }^{4}$ Department of Oral Pathology and Maxillofacial, Faculty of Dental \\ Medicine, Universitas Airlangga, Surabaya, Indonesia \\ ${ }^{5}$ Research Center for Chemistry, Indonesian Institute of Sciences, \\ Kawasan PUSPIPTEK-Serpong, Tangerang Selatan, Banten, \\ Indonesia \\ ${ }^{6}$ Department of Dental Public Health, Faculty of Dental Medicine, \\ Universitas Airlangga, Surabaya 60132, Indonesia
}

\author{
Retno Pudji Rahayu ${ }^{4}$ Dieni Mansur ${ }^{5}$
}

Eur J Dent 2019;13:271-279

\begin{abstract}
Address for correspondence Ira Arundina, MSi, Department of Ora Biology, Faculty of Dental Medicine, Universitas Airlangga, Surabaya 60132, Indonesia (e-mail: arundinafkg@yahoo.com).
\end{abstract}

\section{Abstract}

- Keywords

- coconut shell

- diabetic

- distilled liquid smoke

- traumatic ulcer healing
Objective Distilled liquid smoke (DLS) is a result of coconut processing by-product that not only serves as a natural food preservative but also has a promising therapeutic effect. The healing potential of DLS derived from coconut (Cocos nucifera $\mathrm{L}$ ) shell was investigated on a traumatic ulcer with the diabetic rat.

Materials and Methods DLS was analyzed the component by gas chromatograph mass spectrometry. Diabetic condition was induced by alloxan in 55 male Wistar rats. Ten $\mathrm{mm}$ of traumatic ulcer was made along the labial fornix incisive inferior after the diabetic condition was confirmed. Then DLS coconut shell, benzydamine hydrochloride, and sterile distilled water were applied topically for 3, 5, and 7 days. The potential healing was evaluated based on the expression of nuclear factor kappa beta (NFKB) and tumor necrosis factor alpha (TNF- $\alpha$ ) on macrophages using immunohistochemical staining and the amount of collagen using Masson Trichome staining. The difference between each group was analyzed using one-way analysis of variance. The least significant difference test is used to determine the significant difference $(p<0.05)$.

Results The major compounds found were phenol (36.6\%), 2-methoxyphenol (guaiacol) (25.2\%), furfural (17.8\%), and 4-ethyl-2-methoxyphenol (3.5\%) with 28 other minor constituents. The lowest NFKB and TNF- $\alpha$ expression on macrophage was observed by topical application of DLS derived from coconut shell for 3,5 , and 7 days of treatment. The amount of collagen was increased and indicated by the highest result of DLS compared to others.

Conclusion The DLS derived from coconut (Cocos nucifera $\mathrm{L}$ ) shell was able to improve traumatic ulcer healing in a person with diabetes.
DOI https://doi.org/

10.1055/s-0039-1693527

ISSN 1305-7456.
C2019 Dental Investigation Society
License terms

()(1) $\ominus \circledast$ 


\section{Introduction}

Liquid smoke is a liquid product of wood smoke condensation that is burned indirectly at high temperatures. Liquid smoke contains many compounds formed from the pyrolysis process of wood components, such as cellulose, hemicellulose, and lignin. ${ }^{1}$ Liquid smoke is produced from biomass such as coconut shell, ${ }^{2}$ palm shell, ${ }^{3}$ walnuts, ${ }^{4}$ and rice hull. ${ }^{5}$ Pyrolysis process produces heavy tar, light tar (liquid smoke), charcoal, and uncondensed gases. ${ }^{6}$ Indonesian uses liquid smoke not only as a natural preservative for various processed meat products $^{3,7,8}$ but also apply topically for the skin burns. ${ }^{9}$

Liquid smoke contains polyaromatic hydrocarbon (PAH) such as benzo (a)pyrene that is carcinogenic and causes damage to the amino acid and vitamins. ${ }^{10}$ Purification is the process to separate and eliminate an undesirable component. ${ }^{11}$ One of the purification techniques for liquid smoke is distillation. The purpose of distillation is to remove the undesirable compound like PAH. ${ }^{6}$

The significant component of liquid smoke derived from coconut shell is phenolic compounds. ${ }^{12}$ This compound is a potent antioxidant that is able to bind free radicals such as reactive oxygen species (ROS) formation, inhibit nitric oxide (NO) production, production of proinflammatory cytokines tumor such as tumor necrosis factor alpha $(\mathrm{TNF}-\alpha){ }^{13}$ and the activation of nuclear factor kappa beta $(\mathrm{NF \kappa B}) .{ }^{14}$ The phenolic compound may be responsible for therapeutic effect in liquid smoke derived from coconut shell. Our previous study showed per-oral administration of DLS derived from coconut (Cocos nucifera L) shell owned an analgesic effect, ${ }^{15}$ and topical application can accelerate the contraction and increase the number of fibroblasts in skin burn wound healing. ${ }^{9}$

Oral ulcers in diabetic patients have the potential to delay the healing process, although the diabetic condition is controlled. ${ }^{16}$ Patients with controlled type 2 diabetes mellitus and uncontrolled type 2 diabetes mellitus have an oral mucosal abnormality in the form of the oral ulcer with prevalence of $22 \%{ }^{17}$ and $6.7 \%$, respectively. ${ }^{18}$ Several factors influence the process of delayed healing oral ulcers in diabetes mellitus; one of them is the TNF- $\alpha .{ }^{19}$ Individuals with recurrent aphthous stomatitis without systemic abnormalities increased by two to five times. ${ }^{20}$ Also, free radical levels such as malondialdehyde, NO, and oxidative stress index were higher compared to individuals without recurrent aphthous stomatitis. ${ }^{21}$ Increasing TNF- $\alpha$ expression, not only occurs systemically but also increases in tissue, so oral ulcer in diabetes mellitus has the potential to delay the healing. ${ }^{22}$ Topical treatment, such as benzydamine hydrochloride $(\mathrm{BHCl})$, is unable to improve ulcer healing. It is possible that the mechanism of $\mathrm{BHCl}$ inhibits prostaglandin production and cannot inhibit the production of proinflammatory cytokines. ${ }^{23}$ Phenolic compound on liquid smoke derived from coconut shell ${ }^{12}$ is a potent antioxidant that is able to bind free radicals such as ROS formation and inhibit NO production, production of proinflammatory cytokines tumor such as TNF- $\alpha,{ }^{13}$ and the activation of NFKB. ${ }^{14}$
Despite the exciting findings across data literature, the importance to explore the in vivo activity of DLS derived from coconut (Cocos nucifera $\mathrm{L}$ ) shell and the composition should be conducted. The results bring evidence about the effect of DLS derived from coconut (Cocos nucifera L) shell for topical treatments and the healing potential in traumatic ulcer under diabetic condition. The therapeutic effect combined with safe doses of DLS derived from coconut shell (Cocos nucifera $\mathrm{L}$ ) can give value in therapies or pharmacy.

\section{Materials and Methods}

\section{Raw Materials}

The coconut (Cocos nucifera L) shell was collected from the local market in Surabaya, Indonesia, November 2016. The identification of coconut shell was conducted in the Plant Conservation Centre, Institute of Science, Purwodadi, Indonesia.

\section{Pyrolysis and Distillation of Liquid Smoke}

The pyrolysis process was conducted in the Research and Development of Forest Products Laboratory, Bogor, Indonesia (ISO number 17025:2008). The coconut shell dried at room temperature. The pyrolysis furnace was equipped with a kerosene pump stove as the heater and an encircling reactor with a diameter and height of $30 \mathrm{~cm}$ and $40 \mathrm{~cm}$, respectively. The furnace could be charged with $5000 \mathrm{~g}$ of material. The furnace was connected by a pipeline to the cooling tubes to condense the fumes and generate the liquid smoke. Pyrolysis was carried out at a temperature of $400^{\circ} \mathrm{C}^{6}$ with a heating rate of $3.33^{\circ} \mathrm{C}$ for 4.5 hours.

The yield of the liquid smoke (\%) was calculated using the following formula:

$$
\text { yield }(\%)=\frac{\text { liquid smoke }(g)}{\text { coconut shell }(g)} \times 100
$$

The liquid smoke produced in this process was then settled for 48 hours before filtering with Whatman 52 (Whatman 52, $110 \mathrm{~mm}$ circle, Cat No 1452, GE Healthcare Life Science, Singapore). Then, the purification process was conducted through distillation at 120 to $150^{\circ} \mathrm{C} .^{8}$ The yield of DLS derived from coconut shell (\%) was calculated using the following formula:

$$
\operatorname{DLS}(\%)=\frac{\text { condensed liquid smoke }(m L)}{\text { liquid smoke }(m L)} \times 100
$$

\section{Chemical Analysis of Distilled Liquid Smoke Derived from Coconut Shell}

The 1,000 $\mu \mathrm{L}$ DLS was shaken with 1,500 $\mu \mathrm{L}$ dichloromethane (Merck, pure-analysis or p.a.). The solvent layer was then separated. The sample was re-extracted twice with the 1,000 $\mu \mathrm{L}$ dichloromethane, and the extract layer of solvent was collected.

The components were then determined using gas chromatograph mass spectrometry (GC-MS) model 6890N 
(Agilent Technologies, Inc., Santa Clara, California, United States), equipped with a mass spectrometer detector 5975B and DB-5MS UI column (Agilent Technologies, stationary phase; polyethylene glycol, $30 \mathrm{~m} \times 0.25 \mathrm{~mm}$; i.d. $0.25 \mu \mathrm{m}$ ), the temperature of the injector was $250^{\circ} \mathrm{C}$. The carrier gas was helium at a constant flow rate of $1 \mathrm{~mL} / \mathrm{min}$. The initial oven temperature of the column was raised from $40^{\circ}$ to $300^{\circ} \mathrm{C}$ at $10 \mathrm{C} / \mathrm{min}$ and then maintained for 4 minutes at $300^{\circ} \mathrm{C}$. The mass spectrometer detector conditions were a capillary direct interface temperature of $270^{\circ} \mathrm{C}$, MS Source temperature $230^{\circ} \mathrm{C}$, and MS Quad temperature $150^{\circ} \mathrm{C}$. Ionization energy was 70 $\mathrm{eV}$, mass range was $m / z$ 30-600 a.m.u., and scan rate was 1.4 scan/s. The total flow was $104 \mathrm{~mL} /$ minute, column flow was 1 $\mathrm{mL} /$ minute, and the linear velocity was $36.262 \mathrm{~cm} /$ second-the identification of the individual constituents was based on the comparison between mass spectra and retention time index of authentic reference compounds stored in the NIST14 mass spectral data library.

\section{Animals}

Ethics approval was obtained from the Ethical Clearance of Health Experiment Committee, Faculty of Dental Medicine, Airlangga University, Surabaya with registered number 236/HRECC.FODM/X/2016.

Male Wistar rat, 2-month-old, weighing 120 to $160 \mathrm{~g}$ was used in this experiment. The treatment and experiment of animals were conducted in Animal Testing Laboratory, Faculty of Veterinary, Airlangga University, Surabaya. The animal sample was housed in collective cages with controlled-temperature $\left(27^{\circ} \mathrm{C}\right)$ and artificially lighted rooms on 12 hours light/12 hours dark cycle with free access to water and standard diet.

\section{Diabetic Rat Induction}

This research was an experimental laboratory using a posttest-only of control group design. Fifty-four Wistar rats were intraperitoneally induced with alloxan monohydrate (Alloxan monohydrate A7413, Sigma Aldrich., St. Louis, Missouri, United States) at a dose of $150 \mathrm{mg} / \mathrm{kg}$ to stimulate a diabetic condition. ${ }^{24}$ Preparation of alloxan was performed by dissolving $0.9 \mathrm{~g}$ of alloxan monohydrate into $6 \mathrm{~mL}$ of phosphate-buffered saline to produce a concentrate of $150 \mathrm{mg} / \mathrm{mL}^{25}$ The rats did not receive food or water for more than 12 hours overnight before the induction of alloxan occurred. The development of diabetes mellitus in these animals was confirmed 72 hours after the alloxan induction and confirmed by the level of fasting glucose that was more than $200 \mathrm{mg} / \mathrm{dL}$ using GlucoDR (AGM-2100, All Medicus, Korea). ${ }^{24}$

\section{Traumatic Ulcer Induced in Diabetic Rat}

After the animals confirmed as presenting the condition of diabetes mellitus (fasting glucose $>200 \mathrm{mg} / \mathrm{dL}$ ), a traumatic ulcer sized $10 \mathrm{~mm}$ was created along the labial fornix incisive inferior, ${ }^{26}$ using a round stainless steel blade. ${ }^{27}$ Before this traumatic ulcer being made, the animals were anesthetized using a ketamine/xylazine cocktail. ${ }^{28}$ The traumatic ulcer confirmed after 24 hours with the clinical appearance of a yellowish-white ulcer with a reddish edge.
At this point, the therapeutic topical applications of sterile distilled water, $\mathrm{BHCl}$ (1.25\%, Tantum Verde, Soho, Jakarta, Indonesia) and DLS derived from coconut shell (Cocos nucifera $\mathrm{L}$ ) were performed on the traumatic ulcers of all animals with the following distribution (-Table 1).

\section{NF $\kappa$ B, TNF- $\alpha$ Expression, and Amount of Collagen on Traumatic Ulcer}

After treatment for 3, 5, and 7 days in each group, the rats had terminated, their labial fornix incisive inferior tissue was subjected to biopsy before an immunohistochemistry staining to determine the NFKB and TNF- $\alpha$ expression ( $N F \kappa B$ anti-antibody monoclonal, e381, Abcam) (TNF- $\alpha$ anti-antibody monoclonal, ab220210, Abcam). The histological examination was performed using Masson Trichome staining to determine the amount of collagen. NFKB and TNF- $\alpha$ expression were counted directly from macrophages cells that expressed the NFKB and TNF- $\alpha .{ }^{29}$ The density of collagen expressed as a percentage (\%) was calculated by dividing the area of collagens observed $\left(\mu m^{2}\right)$ by the total area of measurement. All measurements using a light microscope (Nikon H600L microscope; Nikon, Japan) at a magnification of 200× (DS Fi2 300MP digital camera; Nikon, Japan, digital software imaging by Nikkon Image System, Nikon, Japan).

\section{Statistical Analysis}

Data were expressed as the mean standard values deviation for each measurement. The data were then analyzed using analysis of variance (one-way analysis of variance). The least significant difference test was used to determine the significant difference $(p<0.05)$. The SPSS 24.0 for Windows was used for the analysis.

\section{Results}

\section{Pyrolysis and Distillation of Liquid Smoke Derived from Coconut Shell}

The pyrolysis process of 5,000 $\mathrm{g}$ coconut shell was carried out with the final temperature $400^{\circ} \mathrm{C}$ (heating rate $3.33^{\circ} \mathrm{C} / \mathrm{min}$ )

Table 1 Animal distribution in the experiment

\begin{tabular}{|c|c|c|}
\hline Group & Treatment & Duration \\
\hline A3 & Aqua Dest sterile & \multirow{3}{*}{$\begin{array}{l}\text { Once a day for } 3 \text { days } \\
\text { at a dose of } 20 \mu \mathrm{L} / 20 \mathrm{~g} \\
\text { weight }\end{array}$} \\
\hline B3 & $\begin{array}{l}\text { Benzydamine } \\
\text { hydrochloride }\end{array}$ & \\
\hline C3 & $\begin{array}{l}\text { Distilled liquid } \\
\text { smoke }\end{array}$ & \\
\hline A5 & Aqua Dest sterile & \multirow{3}{*}{$\begin{array}{l}\text { Once a day for } 5 \text { days } \\
\text { at a dose of } 20 \mu \mathrm{L} / 20 \mathrm{~g} \\
\text { weight }\end{array}$} \\
\hline B5 & $\begin{array}{l}\text { Benzydamine } \\
\text { hydrochloride }\end{array}$ & \\
\hline C5 & $\begin{array}{l}\text { Distilled liquid } \\
\text { smoke }\end{array}$ & \\
\hline A7 & Aqua Dest sterile & \multirow{3}{*}{$\begin{array}{l}\text { Once a day for } 7 \text { days } \\
\text { at a dose of } 20 \mu \mathrm{L} / 20 \mathrm{~g} \\
\text { weight }\end{array}$} \\
\hline B7 & $\begin{array}{l}\text { Benzydamine } \\
\text { hydrochloride }\end{array}$ & \\
\hline C7 & $\begin{array}{l}\text { Distilled liquid } \\
\text { smoke }\end{array}$ & \\
\hline
\end{tabular}


for 4.5 hours. The pyrolysis produced $51 \%$ of liquid smoke, charcoal $33.87 \%$, and heavy tar $7.28 \%$ (-Table 2 ). Then the liquid smoke from the pyrolysis was distilled at 120 to $150^{\circ} \mathrm{C}$, and the final yield was $84 \%$.

\section{Component of Distilled Liquid Smoke Derived from Coconut Shell}

Around 32 components were identified in DLS derived from coconut shell (Cocos nucifera $\mathrm{L}$ ) (-Table $\mathbf{3}$ ) with seven groups

Table 2 The product of pyrolysis process of coconut shell

\begin{tabular}{|l|l|l|l|}
\hline No & Product & Weight $(\mathbf{g})$ & $\mathbf{( \% )}$ \\
\hline $\mathbf{1}$ & Liquid smoke & 2,240 & 51 \\
\hline $\mathbf{2}$ & Heavy tar & 320 & 7.28 \\
\hline $\mathbf{3}$ & Charcoal & 1,488 & \\
\hline
\end{tabular}

of the identified component using GC-MS (-Table 4). The primary group was phenol, guaiacol, furan, and pyran derivative. The minor group was a ketone, carbonyl, acid, syringol, and alkyl aryl ether.

Phenol was the most significant components of $36.6 \%$, then followed by furfural of $17.8 \%$, guaiacol of $14.4 \%$, 2-methoxy-5-methylphenol of 5.2\%, 4-ethyl-2-methoxyphenol (EMP) of 3.5\%, and 2-methylphenol of 3\% (-Table 3).

\section{NF $\kappa$ B, TNF- $\alpha$ Expression, and Amount of Collagen on Traumatic Ulcer}

The NFאB and TNF- $\alpha$ expression were counted directly from some macrophages that expressed the NFKB and TNF- $\alpha$ ( $\boldsymbol{\sim}$ Fig. 1A-C and $\boldsymbol{\sim}$ Fig. 2A-C, respectively). ${ }^{30,31}$

The NFkB expression was increasing for $3(79.5 \pm 34.63)$, 5 days $(64.5 \pm 16.79)$ and 7 days $(92.67 \pm 23.6)$ on topical

Table 3 Identified components in distilled liquid smoke derived from coconut shell (Cocos nucifera L) using GC-MS

\begin{tabular}{|c|c|c|}
\hline Components & RT & Area (\%) \\
\hline Phenol & 73.555 & 36.6 \\
\hline 2-Methylphenol & 83.889 & 3.0 \\
\hline 2,6-Dimethylphenol & 92.585 & 0.4 \\
\hline 2-Ethyl-phenol & 96.240 & 0.4 \\
\hline 2,3-Dimethylphenol & 98.256 & 1.1 \\
\hline 2,4,6-Trimethylphenol & 107.079 & 0.1 \\
\hline p-Cresol & 87.796 & 2.0 \\
\hline 2-Methoxyphenol & 90.191 & 14.4 \\
\hline 2-Methoxy-3-methylphenol & 96.618 & 0.1 \\
\hline 2-Methoxy-3-methylphenol & 102.920 & 0.8 \\
\hline 2-Methoxy-5-methylphenol & 104.306 & 0.5 \\
\hline 2-Methoxy-5-methylphenol & 105.314 & 5.2 \\
\hline 4-Ethyl-2-methoxyphenol & 117.413 & 3.5 \\
\hline 4-Ethyl-2-methoxyphenol & 117.917 & 0.1 \\
\hline Trans-Isoeugenol & 134.805 & 0.1 \\
\hline Trans-Isoeugenol & 140.477 & 0.1 \\
\hline 2-Methoxy-4-propylphenol & 129.260 & 0.4 \\
\hline Furfural & 49.987 & 17.8 \\
\hline 2-Furanmethanol, acetate & 75.193 & 0.1 \\
\hline 3,4-Dimethyl-2-cyclopentene-1-one & 75.823 & 0.2 \\
\hline 2,3-Dimethyl-2-cyclopentene-1-one & 82.503 & 0.3 \\
\hline 2-Methyl-2-cyclopentene-1-one & 65.867 & 0.7 \\
\hline 3-Methylcyclopentane-1,2-dione & 80.738 & 0.7 \\
\hline 3-Ethyl-2-hydroxy-2-cyclopenten-1-one & 93.971 & 0.2 \\
\hline 4-Methoxy benzoic acid methyl ester & 131.024 & 0.2 \\
\hline 4-Oxo-pentanoic acid methyl ester & 74.689 & 0.2 \\
\hline 1H-Inden-1-one, 2,3-dihydro-2-methyl & 122.202 & 0.1 \\
\hline Acetic acid, phenyl ester & 85.023 & 0.6 \\
\hline 2,6-Dimethoxyphenol & 127.118 & 0.6 \\
\hline 2-Methoxy-3- (2-propenyl)-phenol & 128.00 & 0.3 \\
\hline 3,4-Dimethoxytoluene & 111.238 & 0.3 \\
\hline 3,5-Dimethoxy-4-hydroxytoluene & 139.343 & 0.1 \\
\hline
\end{tabular}


Table 4 Classes of components in distilled liquid smoke derived from coconut shell (Cocos nucifera $\mathrm{L}$ )

\begin{tabular}{|l|l|l|}
\hline Classes & $\begin{array}{l}\text { Identified } \\
\text { compound }\end{array}$ & $\begin{array}{l}\text { Percentage } \\
\text { (\%) }\end{array}$ \\
\hline Phenol and its derivative & 7 & 43.6 \\
\hline Guaiacol and its derivative & 10 & 25.2 \\
\hline Furan and pyran derivative & 2 & 17.9 \\
\hline Ketone & 5 & 2.1 \\
\hline Carbonyl and acid & 4 & 1.1 \\
\hline Syringol and its derivative & 2 & 0.9 \\
\hline Alkyl aryl ether & 2 & 0.4 \\
\hline Total identified & & 91.8 \\
\hline
\end{tabular}

application of DLS. The topical application of distilled liquid smoke on traumatic ulcer for 3, 5, and 7 days showed the lower $\mathrm{NF} \kappa \mathrm{B}$ expression compared to $\mathrm{BHCl}$ and sterile distilled water. NFKB expression of DLS (37.83 \pm 8.19 ) for 3 days was significantly lower than $\mathrm{BHCl}(112.17 \pm 16.29)$ and sterile distilled water $(88.5 \pm 16.84)$. While the NFKB expression was significantly lower than $\mathrm{BHCl}(80.17 \pm 18.06)$ when compared to DLS $(37.83 \pm 8.19)$ for 5 days ( - Fig. 1D).

The TNF- $\alpha$ expression showed the same pattern after topical application of DLS, $\mathrm{BHCl}$, and sterile distilled water increased for 3, 5, and 7 days of application. Only topical application for 3 days showed the different TNF- $\alpha$ expression. Topical application of DLS (34.5 \pm 3.27$)$ for 3 days was significantly lower than $\mathrm{BHCl}(38 \pm 6.84)$ and topical application of $\mathrm{BHCl}(38 \pm 6.84)$ for 3 days was significantly lower than sterile distilled water (48.5 \pm 6.38) (-Fig. 2D).

The amount of collagen was counted microscopely as a density of collagen (-Fig. $\mathbf{3 A - C}$ ). The topical application of DLS derived from coconut shell (Cocos nucifera $\mathrm{L}$ ) on traumatic ulcer of the diabetic patient for 3, 5, and 7 days showed the highest amount of collagen compared to $\mathrm{BHCl}$ and sterile distilled water. The amount of collagen was significantly different between 3 and 5 days of topical application. The topical application of DLS $(67.15 \pm 6.09)$ for 3 days was significantly higher than $\mathrm{BHCl}(56.14 \pm 8.07)$ and sterile distilled water (39.45 \pm 10.82 ), while topical application of $\mathrm{BHCl}$ (56.14 \pm 8.07 ) was significantly higher than sterile distilled water ( $39.45 \pm 10.82$ ). The 5 days topical application of DLS (84.27 \pm 6.76$)$ was significantly higher than $\mathrm{BHCl}(68.24$ $\pm 9.23)$, while topical application of $\mathrm{BHCl}(68.24 \pm 9.23)$ was higher than sterile distilled water $(77.53 \pm 3.69)$ (-Fig. 3D).

\section{Discussion}

Pyrolysis process of coconut shells was carried out at $400^{\circ} \mathrm{C}$ with a heating rate of $3.3^{\circ} \mathrm{C} / \mathrm{min}$. The process resulted in $51 \%$
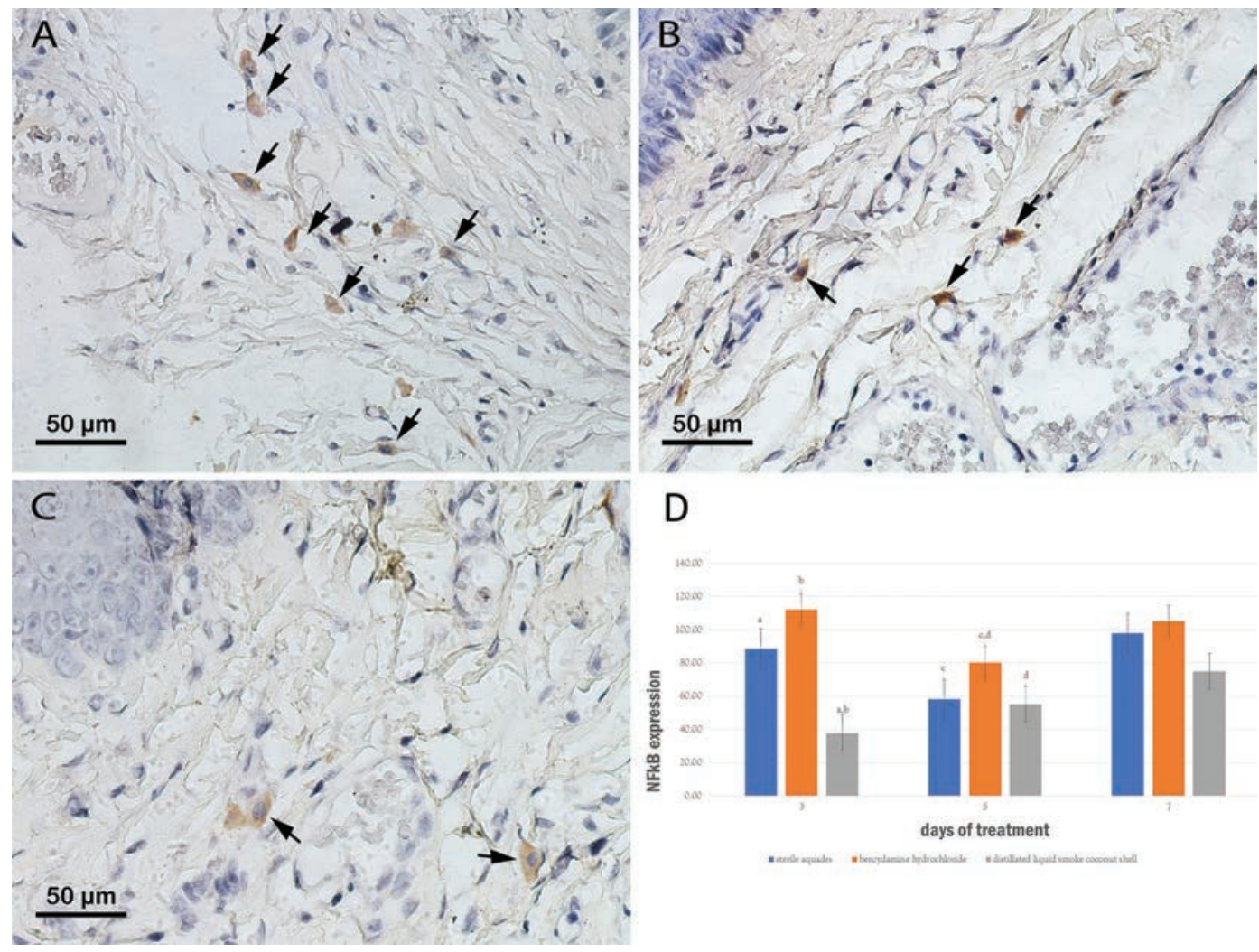

Fig. 1 The macrophage that expresses nuclear factor Kappa B (NFKB) on traumatic ulcer with diabetic rat (arrow). (A) The traumatic ulcer treated with sterile distilled water. (B) Traumatic ulcer treated with benzydamine hydrochloride (BHCl). (C) Traumatic ulcer treated with liquid smoke coconut shell (Cocos nucifera L). (D) NFkB expression on the traumatic ulcer. The same character means a significant difference between each group $(p<0.05)$. 

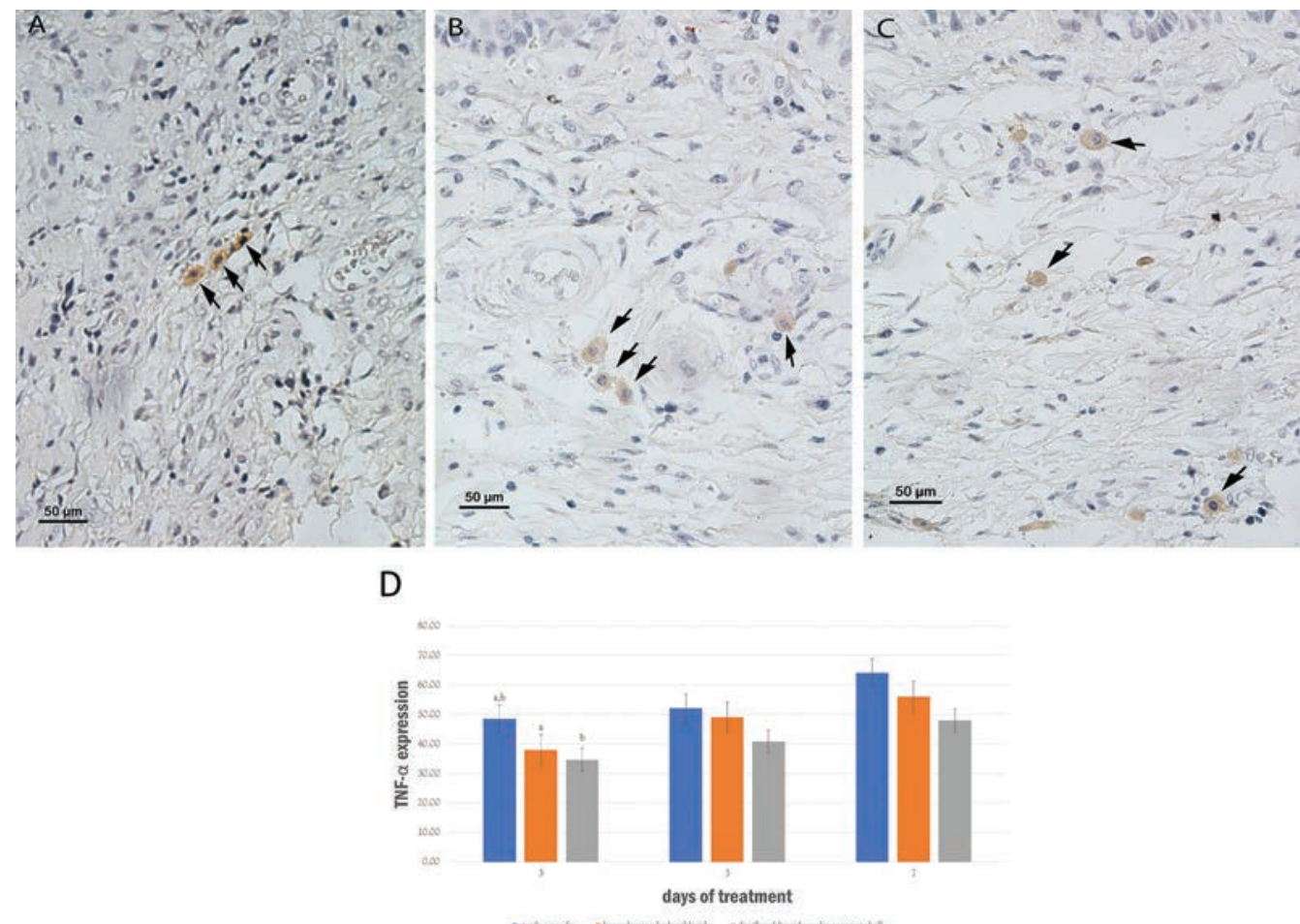

Fig. 2 The macrophage that expresses tumor necrosis factor-alpha (TNF- $\alpha$ ) on traumatic ulcer with diabetic rat (arrow). (A) The traumatic ulcer treated with sterile distilled water. (B) Traumatic ulcer treated with benzydamine hydrochloride (BHCl). (C) Traumatic ulcer treated with liquid smoke coconut shell (Cocos nucifera L). (D) TNF- $\alpha$ expression on the traumatic ulcer. The same character means a significant difference between each group $(p<0.05)$.
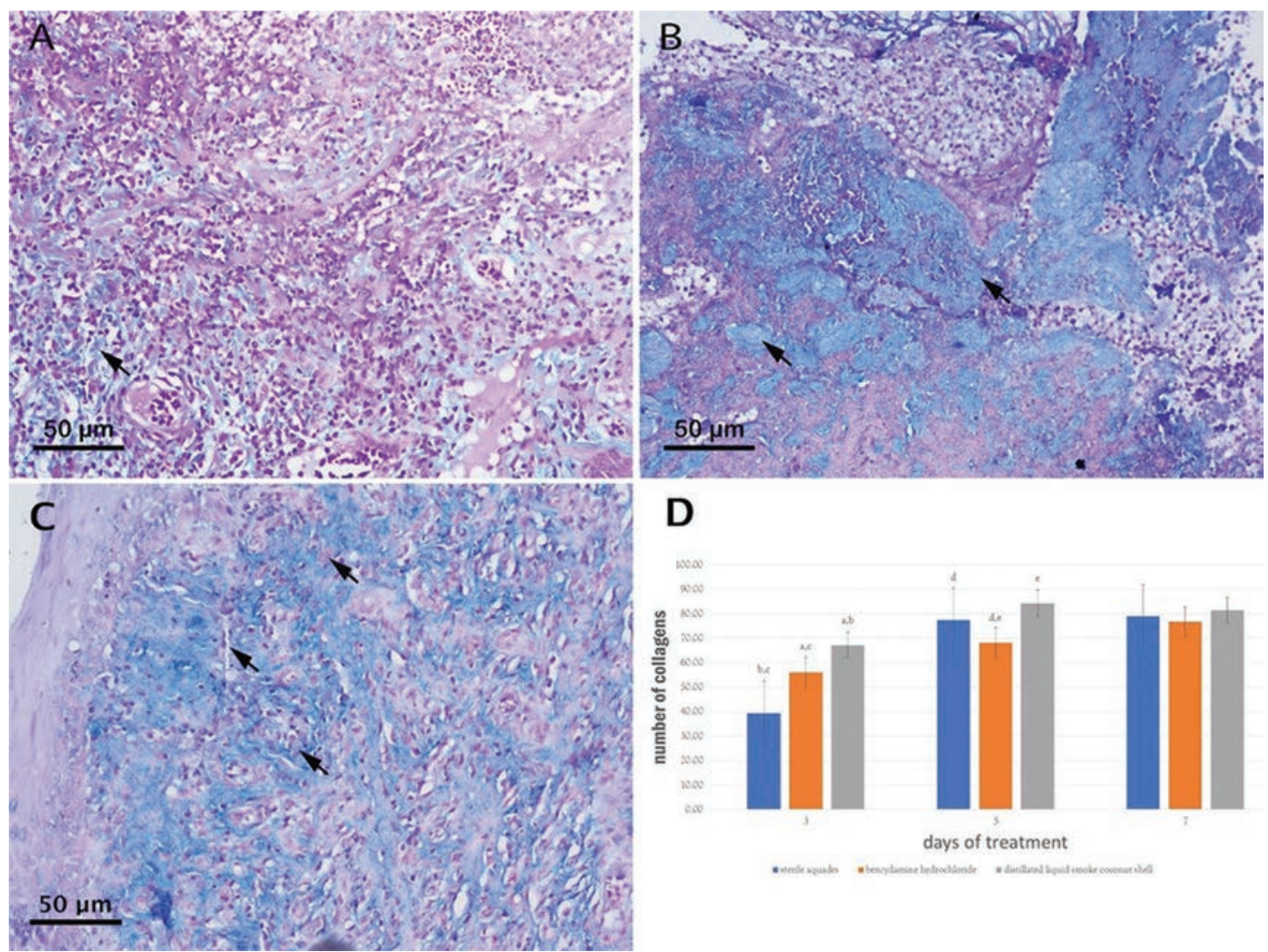

D

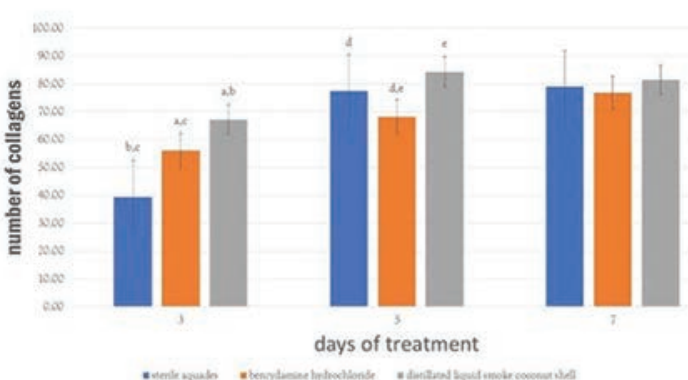

Fig. 3 The amount of collagen on traumatic ulcer with diabetic rat (arrow). (A) The traumatic ulcer treated with sterile distilled water. (B) Traumatic ulcer treated with benzydamine hydrochloride (BHCl). (C) Traumatic ulcer treated with liquid smoke coconut shell (Cocos nucifera $\mathrm{L}$ ). (D) Amount of collagen on the traumatic ulcer. The same character means a significant difference between each group $(p<0.05)$. 
of liquid smoke, $7.28 \%$ of heavy tar, and $33.87 \%$ of charcoal. Ali et al produced $68.8 \pm 1.5 \%$ of liquid smoke and heavy tar and $19.7 \pm 1.3 \%$ of charcoal with the final temperature of $995^{\circ} \mathrm{C}, 3^{32}$ while Lombok et al produced $14.71 \%$ of liquid smoke, $2.29 \%$ of heavy tar, and $28.75 \%$ of charcoal with the final temperature of $400^{\circ} \mathrm{C} .{ }^{6}$ The differences in these results were due to the different quality of coconut shell, the design of pyrolysis reactor, ${ }^{33}$ the final temperature, ${ }^{33}$ and the heating rate..$^{34}$ The final temperature of $400^{\circ} \mathrm{C}$ was chosen for the pyrolysis process due to the formation of liquid smoke derived from coconut shell that was optimal at this temperature. The principle of the pyrolysis process is the decomposition of biomass that contains cellulose, hemicellulose, and lignin at high temperatures. ${ }^{33}$ Liquid smoke as the pyrolysis product was obtained at the maximum temperature of 400 to $550^{\circ} \mathrm{C} .3^{35}$ Temperature below $300^{\circ} \mathrm{C}$ produced a dominant tar. Temperature above $450^{\circ} \mathrm{C}$ will decrease the decomposition process because of the decline in volatile condensable product. ${ }^{34}$ The temperature more than $700^{\circ} \mathrm{C}$ will increase the carbon content in the form of PAH, such as pyrene and phenanthrene, due to decarboxylation and dehydration reactions. ${ }^{36}$ Lignin is the dominant component in a coconut shell, ${ }^{37}$ which decomposes at 300 to $550^{\circ} \mathrm{C},{ }^{38}$ and produces major compounds in liquid smoke, that is, phenolic compounds (phenol and guaiacol). ${ }^{38,39}$ The final temperature of pyrolysis determines the content of phenol in the liquid smoke coconut shell. The optimal temperature of phenol formation is $400^{\circ} \mathrm{C}$. Temperature of $350^{\circ} \mathrm{C}$ produced $2.92 \%$ of phenol, temperature of $400^{\circ} \mathrm{C}$ produced $4.63 \%$ of phenol, and temperature of $450^{\circ} \mathrm{C}$ produced $3.67 \%$ of phenol. ${ }^{40}$ Budaraga et al also showed similar results, the final temperature of $400^{\circ} \mathrm{C}$ produced $23.45 \%$ phenolic compound, while the final temperature lower than $400^{\circ} \mathrm{C}$ resulted in $22.26 \%$ of phenolic compound. ${ }^{37}$ This happened because liquid smoke and phenol reached the maximum concentration at temperatures between 400 and $550^{\circ} \mathrm{C}$, and then declined. At temperatures higher than $600^{\circ} \mathrm{C}$, the product will convert into gas and cannot be condensed. ${ }^{36}$

Liquid smoke contains PAH such as benzo (a)pyrene that is carcinogenic and causes damage to amino acids and vitamins. ${ }^{10}$ Purification is the process of separating and eliminating an undesirable component like benzo (a)pyrene. ${ }^{11}$ One of the purification methods is distillation. The distillation process in liquid smoke is carried out to remove that compound. ${ }^{6}$

The main compound of DLS derived from coconut shell (Cocos nucifera $\mathrm{L}$ ) is phenol (36.6\%), guaiacol (14.4\%), and EMP (3.5\%). This proportion was different in the liquid smoke derived from coconut shell that pyrolyzed at $400^{\circ} \mathrm{C}$ and not distilled. Another study showed that the proportion of guaiacol and EMP was 3.08 and 8.34\%, respectively, in liquid smoke derived from coconut shell with pyrolysis at temperature of 350 to $420^{\circ} \mathrm{C} .{ }^{41}$ Therefore, phenol, guaiacol, and EMP compounds were found in liquid smoke coconut shells even with or without distillation process.

The topical application of coconut shell distilled liquid smoke to the traumatic ulcer with diabetes showed the expression of NFKB and TNF- $\alpha$ in macrophage cells that were lower than $\mathrm{BHCl}$ and sterile distilled water. Significant differences were observed after topical application for 3 days.
Mechanisms that might be involved in this process were the content of phenolic compounds such as EMP and guaiacol in distilled coconut shell liquid smoke. The guaiacol is a phenolic compound with two functional groups in the form of hydroxyl groups $(-\mathrm{OH})$ and methoxy groups $\left(-\mathrm{OCH}_{3}\right){ }^{42}$ This compound has high reactivity to free radicals. ${ }^{43}$ The guaiacol reactivity is related to the ability of-OH to bind free radicals, ${ }^{44}$ because of its high ionization potential, which is capable of forming strong intermolecular and intramolecular hydrogen bonds. ${ }^{45}$ Guaiacol can inhibit superoxide radicals $\left(\mathrm{O}_{2}{ }^{-}\right)$ by giving hydrogen atoms $\left(\mathrm{H}^{+}\right)$to- $\mathrm{OH}$ to form $\mathrm{H}_{2} \mathrm{O}^{46}$ While EMP plays a role in binding free radicals derived from nitrogen. Free radicals from nitrogen such as NO are produced by L-arginine and nicotinamide adenine dinucleotide phosphate through nitric oxide synthase (NOS). ${ }^{47}$ NO will react with $\mathrm{O}_{2}^{-}$and produce peroxynitrite ( $\left.\mathrm{ONOO}^{-}\right)$. EMP is a guaiacol compound that has stronger antioxidant properties than guaiacol itself. EMP as a potent NO scavenger can protect cells from these free radicals by binding $\mathrm{ONOO}^{-48}$ Binding $\mathrm{O}_{2}^{-}$by guaiacol and $\mathrm{ONOO}^{-}$by EMP will inhibit phosphorylation and activation of NFKB inhibitor kinase (IKK), IkB degradation or inhibit phosphorylation and translocation of p65 to the cell nucleus so that NFkB decreases. ${ }^{14}$ The decrease in NFkB causes a decrease in TNF- $\alpha$.

The reduction in NFKB expression was also significantly observed after 5 days application of distilled coconut shell liquid smoke but did not reduce the TNF- $\alpha$ expression. The activation of $\mathrm{NF}$ B B during the inflammation process not only produces pro-inflammatory cytokines TNF- $\alpha$ but also can activate gene expression to produce other proinflammatory cytokines involved in inflammation, such as interleukin $1 \beta$ (IL-1ß) and interleukin 6 (IL-6). ${ }^{49}$ It is possible that distilled coconut shell liquid smoke also has a mechanism for the production of IL-1 $\beta$ and IL- 6 through activation of NFkB. Thus, TNF- $\alpha$ expression was not significantly different when given 5 days of DLS.

Coconut shell liquid smoke not only affects the inflammatory phase through the changed of $\mathrm{NF}_{\mathrm{K} B} \mathrm{~B}$ expression that becomes lower but also played a role in the proliferation phase by increasing collagen formation in traumatic ulcers with diabetes mellitus. The topical application of coconut shell liquid smoke showed a higher amount of collagen compared to topical application of $\mathrm{BHCl}$ and sterile distilled water. The amount of collagen observed increased with the duration of topical application in traumatic ulcers. This difference in the amount of collagen was significantly observed after topical application for 3 and 5 days. The mechanism that can be explained was the topical application of coconut shell liquid smoke to the traumatic ulcer due to the increasing fibroblast cells. ${ }^{9}$ Fibroblasts synthesize different amounts of collagen because fibroblasts also synthesize the degradation factor, collagenase. The granulation tissue formation at the proliferation stage of the wound healing process is causing fibroblasts to reduce collagenase resulting in a decrease in the degradation process. Also, at this stage, fibroblasts undergo the apoptosis process so that the granulation tissue will be replaced by collagen..$^{50}$ In diabetic conditions, the fibroblast apoptosis process occurs through a 
mechanism that involves activation of the FOXO1 transcription factor by increasing caspase-3 activation by advanced glycation end-products (AGEs). ${ }^{51,52}$ AGEs can stimulate the apoptosis process through a mechanism involving the ROS formation in fibroblasts. ${ }^{33}$ The previous study by Yang et al that the topical application of liquid smoke can reduce the ROS formation ${ }^{13}$ and increase the number of fibroblast cells. ${ }^{9}$ The results of this study that showed a change in the $\mathrm{NF}_{\kappa} \mathrm{B}$ expression to be lower and an increase in the amount of collagen, it might explain the mechanism of the traumatic ulcer healing process with diabetes mellitus after the application of coconut shell liquid smoke. The topical application of coconut shell liquid smoke to the traumatic ulcer causes a decrease in the ROS formation, resulting in a decrease in the NFkB expression to produce TNF- $\alpha$. The decrease in production of pro-inflammatory cytokine resulted in a decrease in activation of the FOXO1 transcription factor, so the caspase- 3 activation that caused fibroblast apoptosis also decreased. Decreasing fibroblast apoptosis will increase collagen synthesis, and the proliferation phase in the traumatic ulcer healing process can be achieved so that the healing process will be faster.

This study was the first study to analyze the therapeutic potential of coconut shell DLS in traumatic ulcers with diabetes mellitus. This study showed that topical application of DLS coconut (Cocos nucifera L) shell could affect or increase the traumatic ulcer healing process. The limitations of this study only analyzed the mechanism on the inflammatory phase but also analyzed the further mechanism in the proliferation phase. In this context, the mechanism of coconut shell DLS to increase the amount of collagen due to the TNF- $\alpha$ expression reduction still had not been fully explained. Therefore, it needs further analysis.

\section{Conclusion}

The DLS coconut shell (Cocos nucifera $\mathrm{L}$ ) examined in the current study showed the inhibition of NFKB, TNF- $\alpha$ expression and increased the amount of collagen when given topically. Those results indicate the promising pharmaceutical potential of DLS coconut shell (Cocos nucifera $\mathrm{L}$ ) to promote a traumatic ulcer healing. Accordingly, the pharmacological actions of distilled liquid smoke coconut shell (Cocos nucifera L) may be related to the presence of phenol, guaiacol, and EMP as the significant component in the distilled liquid smoke coconut shell (Cocos nucifera L).

\section{Funding \\ None. \\ Conflict of Interest \\ None declared.}

\section{References}

1 Wagiman FX, Ardiansyah A, Witjaksono. Activity of coconut-shell liquid-smoke as an insecticide on the rice brown planthopper (Nilaparvata lugens). J Agric Biol Sci 2014; 9(9):293-296
2 Zuraida I, Sukarno, Budijanto S. Antibacterial activity of coconut shell liquid smoke (CS-LS) and its application on fish ball preservation. Int Food Res J 2011;18:405-410

3 Achmadi SS, Mubarik NR, Nursyamsi R, Septiaji P. Characterization of redistilled liquid smoke of oil-palm shells and its application as fish preservatives. J Appl Sci (Faisalabad) 2013;13(3):401-408

4 Yusnaini S, Soeparno S, Suryanto E, Armunanto R. Physical, chemical and sensory properties of Kenari (Canariun indicum L.) shell liquid smoke-immersed-beef on different level of dilution. J Indones Trop Anim Agric 2012;37(1):27-33

5 Kim SP, Yang JY, Kang MY, Park JC, Nam SH, Friedman M. Composition of liquid rice hull smoke and anti-inflammatory effects in mice. J Agric Food Chem 2011;59(9):4570-4581

6 Lombok JZ, Setiaji B, Trisunaryanti W, Wijaya K. Effect of pyrolysis temperature and distillation on character of coconut shell liquid smoke. Asian J Sci Technol 2014;5(6):320-325

7 Purba R, Suseno SH, Izaki AF, Muttaqin S. Application of liquid smoke and chitosan as natural preservatives for tofu and meatballs. Int J Appl Sci Technol 2014;4(2):212-217

8 Desniorita M. The effect of adding liquid smoke powder to shelf life of sauce. Int J Adv Sci Eng Inf Technol 2015;5(6):457-459

9 Tarawan VM, Mantilidewi KI, Dhini IM, Radhiyanti PT, Sutedja E. Coconut shell liquid smoke promotes burn wound healing. J Evid Based Complementary Altern Med 2016;38:1-5

10 Anggraini SPA, Yuniningsih S. Liquid smoke purification process for benzo (a) pyrene levels lowering on food safety. J Agric Food Tech 2013;3(12):1-4

11 Budaraga IK, Arnim, Marlida Y, Usman B. Characteristics of cinnamon liquid smoke produced using several purification techniques. Am J Food Sci Nutr Res 2016;3(2):16-21

12 Budijanto S, Hasbullah R, Prabawati S, Zuraida I. Identifikasi dan Uji Keamanan Asap Cair Tempurung Kelapa untuk Produk Pangan. J Pascapanen 2008;5(1):32-40

13 Yang JY, Kang MY, Nam SH, Friedman M. Antidiabetic effects of rice hull smoke extract in alloxan-induced diabetic mice. J Agric Food Chem 2012;60(1):87-94

14 Costa G, Francisco V, Lopes MC, Cruz MT, Batista MT. Intracellular signaling pathways modulated by phenolic compounds: application for new anti-inflammatory drugs discovery. Curr Med Chem 2012;19(18):2876-2900

15 Meircurius Dwi CS, Tantiana T, Arundina I. Analgesic effect of coconut shell (Cocos nucifera L) liquid smoke on mice. Dent J (Majalah Kedokt Gigi) 2012;45(3):156-160.

16 Tripathi R, Tripathi K. Management of non-healing oral ulcer in diabetic patient using topical application of epidermal growth factor: a case report. Sch Acad J Biosci 2015;3(8):640-643

17 Bajaj S, Prasad S, Gupta A, Singh VB. Oral manifestations in type-2 diabetes and related complications. Indian J Endocrinol Metab 2012;16(5):777-779

18 Ravindran R, Deepa M, Sruthi A, et al. Evaluation of oral health in type ii diabetes mellitus patients. OMPJ 2015;6(1):525-531

19 Xu F, Zhang C, Graves DT. Abnormal cell responses and role of TNF- $\alpha$ in impaired diabetic wound healing. BioMed Res Int 2013;2013754802:754802

20 Eguia-del Valle A, Martinez-Conde-Llamosas R, López-Vicente J, Uribarri-Etxebarria A, Aguirre-Urizar J-M. Salivary levels of tumour necrosis factor-alpha in patients with recurrent aphthous stomatitis. Med Oral Patol Oral Cir Bucal 2011;16(1):e33-e36

21 Avci E, Akarslan ZZ, Erten H. Coskun-Cevher S. Oxidative stress and cellular immunity in patients with recurrent aphthous ulcers. Braz J Med Biol Res 2014;47(5):355-360

22 Brizeno LA, Assreuy AM, Alves AP, et al. Delayed healing of oral mucosa in a diabetic rat model: implication of TNF- $\alpha$, IL-1 $\beta$ and FGF-2. Life Sci 2016;155:36-47

23 Parashar A. Mouthwashes and their use in different oral conditions. Sch J Dent Sci J Dent Sci 2015;2(2B):186-191 
24 Radenković M, Stojanović M, Prostran M. Experimental diabetes induced by alloxan and streptozotocin: the current state of the art. J Pharmacol Toxicol Methods 2016;78:13-31

25 Bako HY, Mohammad JS, Waziri PM, Bulus T, Gwarzo MY, Zubairu MM. Lipid profile of alloxan-induced diabetic Wistar rats treated with methanolic extract of Adansonia digitata fruit pulp. Sci World J 2014;9(2):19-24

26 Hitomi S, Ono K, Miyano K, et al. Novel methods of applying direct chemical and mechanical stimulation to the oral mucosa for traditional behavioral pain assays in conscious rats. J Neurosci Methods 2015;239:162-169

27 Kılıç C, Güleç Peker EG, Acartürk F, Kılıçaslan SM, Çoşkun Cevher S. Investigation of the effects of local glutathione and chitosan administration on incisional oral mucosal wound healing in rabbits. Colloids Surf B Biointerfaces 2013;112:499-507

28 He S, Atkinson C, Qiao F, Chen X, Tomlinson S. Ketamine-xylazine-acepromazine compared with isoflurane for anesthesia during liver transplantation in rodents. J Am Assoc Lab Anim Sci 2010;49(1):45-51

29 Rahayu RP, Prasetyo RA, Purwanto DA, Kresnoadi U, Iskandar RPD, Rubianto M. The immunomodulatory effect of green tea (Camellia sinensis) leaves extract on immunocompromised Wistar rats infected by. Candida albicans. Vet World 2018;11(6):765-770

30 Chawla H, Urs AB, Augustine J. Association of macrophages with angiogenesis in oral epithelial dysplasia, oral verrucous carcinoma, an immunohistochemical study. Appl Immunohistochem Mol Morphol 2015;25(3):203-208

31 Mohamad SH. Tumor necrosis factor-alpha (TNF- $\alpha$ ) expression in mice infected with aspergillus fumigatus using immunohistochemical technique. IJSBAR 2016;25(1):183-189

32 Ali I, Bahaitham H, Naebulharam R. A comprehensive kinetics study of coconut shell waste pyrolysis. Bioresour Technol 2017;235 March:1-11

33 Kan T, Strezov V, Evans TJ. Lignocellulosic biomass pyrolysis: a review of product properties and effects of pyrolysis parameters. Renew Sustain Energy Rev 2016;57:1126-1140

34 Gao Y, Yang Y, Qin Z, Sun Y. Factors affecting the yield of bio-oil from the pyrolysis of coconut shell. Springerplus 2016;5(333):333

35 Roslam WIWN, Hisham MWM, Yarmo MA, Hin TY. A review on bio-oil production from biomass by using pyrolysis method. Renew Sustain Energy Rev 2012;16(8):5910-5923

36 Akhtar J, Saidina Amin N. A review on operating parameters for optimum liquid oil yield in biomass pyrolysis. Renew Sustain Energy Rev 2012;16(7):5101-5109

37 Budaraga IK, Armin, Marlida Y, Bulanin U. Analysis of liquid smoke chemical components with GC MS from different raw materials variation production and pyrolysis temperature level. Int J Chemtech Res 2016;9(6):694-708

38 Stefanidis SD, Kalogiannis KG, Iliopoulou EF, Michailof CM, Pilavachi PA, Lappas AA. A study of lignocellulosic biomass pyrolysis via the pyrolysis of cellulose, hemicellulose and lignin. J Anal Appl Pyrolysis 2014;105:143-150
39 Rout T, Pradhan D, Singh RK, Kumari N. Exhaustive study of products obtained from coconut shell pyrolysis. J Environ Chem Eng 2016;4(3):3696-3705

40 Yuniningsih S, Anggraini SPA. Characterization of liquid smoke from coconut shell to be applicated as safe food preservatives for human health. J Agric Food Chem 2013;3(2):1-5

41 Hadanu R, Apituley DAN. Volatile compounds detected in coconut shell liquid smoke through pyrolysis at a fractioning temperature of 350-420C. Makara J. Science 2016;20(3):95-100

42 Scozzafava A, Passaponti M, Supuran CT, Gulcin I. Carbonic anhydrase inhibitors: guaiacol and catechol derivatives effectively inhibit certain human carbonic anhydrase isoenzymes (hCA I, II, IX, and XII) J Enzyme Inhib Med Chem 2014;6366:1-6

43 Lauraguais A, Coeur-tourneur C, Cassez A, Deboudt K, Fourmentin M, Choel M. Atmospheric reactivity of hydroxyl radicals with guaiacol (2- methoxyphenyl), a biomass burning emitted compound: secondary organic aerosol formation and gas-phase oxidation products. Atmos Environ 2014;86:155-163

44 Gülçin I, Beydemir Ş. Phenolic compounds as antioxidants: carbonic anhydrase isoenzymes inhibitors. Mini Rev Med Chem 2013;13(3):408-430

45 Varfolomeev MA, Abaidullina DI, Solomonov BN, Verevkin SP, Emel'yanenko VN. Pairwise substitution effects, inter- and intramolecular hydrogen bonds in methoxyphenols and dimethoxybenzenes. Thermochemistry, calorimetry, and first-principles calculations. J Phys Chem B 2010;114(49):16503-16516

46 Nimse SB, Pal D. Free radicals, natural antioxidants, and their reaction mechanisms. RSC Advances 2015;5:27986-28006

47 Haan JB, Jandeleit-Dahm KA, Allen TJ. Role of Oxidative Stress and Targeted Antioxidant Therapies in Experimental Models of Diabetic Complications. Springer Science; 2011. doi10.1007/978-1-60761-956-7

48 Huang MH, Chang LW, Sung WC, Vong WJ, Wang BS. Protective effects of three smoke flavouring phenols on oxidative damage and nitric oxide production. Food Chem 2011;126(4):1655-1661

49 Ashor AW, Siervo M, Lara J, Oggioni C, Afshar S, Mathers JC. Effect of vitamin C and vitamin E supplementation on endothelial function: a systematic review and meta-analysis of randomised controlled trials. Br J Nutr 2015;113(8):1182-1194

50 Tracy LE, Minasian RA, Caterson EJ. Extracellular matrix and dermal fibroblast function in the healing wound. Adv Wound Care (New Rochelle) 2016;5(3):119-136

51 Desta T, Li J, Chino T, Graves DT. Altered fibroblast proliferation and apoptosis in diabetic gingival wounds. J Dent Res 2010;89(6):609-614

52 Sun K, Wang W, Wang C, et al. AGEs trigger autophagy in diabetic skin tissues and fibroblasts. Biochem Biophys Res Commun 2016;471(3):355-360

53 Garcia-Bailo B, El-Sohemy A, Haddad PS, et al. Vitamins D, C, and $E$ in the prevention of type 2 diabetes mellitus: modulation of inflammation and oxidative stress. Biologics 2011;5:7-19 